Asian Australas. J. Biosci. Biotechnol. 2020, 5 (3), 78-87

Asian-Australasian Journal of

Bioscience and Biotechnology

ISSN 2414-1283 (Print) 2414-6293 (Online)

www.ebupress.com/journal/aajbb

\title{
Article \\ Comparative seasonal assessment on the quality of Black Bengal goat oocytes in view of in vitro embryo production
}

Shikha Sarkar, Md. Saiful Islam, Md. Enayet Kabir, Falguni Dadok, Md. Abdullah Al Zaber and Md. Shefath Abdulla

Department of Animal Production and Management, Sher-e-Bangla Agricultural University, Dhaka-1207, Bangladesh

*Corresponding author: Md. Saiful Islam, Associate Professor, Department of Animal Production and Management, Sher-e-Bangla Agricultural University, Dhaka-1207, Bangladesh. Phone: +8801725434279; Email: saiful.apma@sau.edu.bd

Received: 19 November 2020/Accepted: 22 December 2020/ Published: 31 December 2020

\begin{abstract}
In vitro maturation (IVM) of oocytes provide an excellent opportunity for cheap and abundant embryos for carrying out animal improvement. With the aim for studying the quality of oocyte in different seasons of Black Bengal goat, both right and left ovaries were collected from the slaughter houses. For each of the specimens, gross parameters such as right, left, corpus luteum (CL)-present and corpus luteum (CL)-absent group were evaluated on the basis of weight $(\mathrm{g})$, length $(\mathrm{cm})$, width $(\mathrm{cm})$, follicles aspirated and number and state of cumulus-oocyte-complexes (COCs), normal COCs and abnormal COCs, the effect of season on cumulus oocyte complexes (COCs) of goat oocytes. Our study revealed that the average number of follicles and oocytes recovery rate were higher in summer than in winter season and recovery rate of grade A and B oocytes were higher in summer than that of in winter and recovery rate of grade $\mathrm{C}$ and $\mathrm{D}$ were higher in winter than that of in summer. In the present study a significantly greater number of oocytes per ovary were recovered from ovaries without a corpus luteum than from ovaries with a corpus luteum. So the summer was the best season for recovery of COCs which have a worthy competence to be matured in vitro.
\end{abstract}

Key words: In vitro maturation, corpus luteum, cumulus-oocyte-complexes (COCs)

\section{Introduction}

Goat is a multi-functional animal and contributes a great rule to the rural economy of Bangladesh. Goat significantly contributes to the national GDP through the production of 130000 MT of meat (25\% total meat), 1312000 MT milk and 391000 MT Skin each year (FAO, 2003). Goat population has increased at the rate of $10 \%$ per annum with a continuous reduction of cattle $(0.21 \%$ per annum) from 1970 to 2003 (FAO, 1970 and 2003).

In vitro maturation (IVM) of oocytes provide a good opportunity for cheap and abundant embryos to carry out research and to apply in emerging biotechnologies sectors like cloning and transgenic (Li et al., 2006). Seasonal effect was found an important consideration in this respect, especially in buffalo (Kadoom, 1995 and Das et al., 1996), mare (Bruck et al., 1996 and Colleoni et al., 2004) and cattle (Silva et al., 2006). In case of buffalo, the incubation temperature during the in vitro maturation (IVM) influenced the fertilization rate but had no effect on maturation and subsequent embryo development (Ravindranatha et al., 2003). Al-Katanani et al. (2002) reported that summer depression in oocyte quality in Holstein cow was evident, but cooling cow for 42 days did not alleviate that seasonal effect.

The present study was, therefore, designed with the objectives to evaluate oocyte recovery rates and their quality from goat ovaries collected at local abattoir in two different seasons, to characterize the ovary and oocyte 
physically in Black Bengal goat in two different seasons and to assess the quality of oocytes recovered from Black Bengal goat in two different seasons.

\section{Materials and Methods}

\subsection{Experimental site}

The experiment was conducted in the laboratory of the Dept. of Animal Production \& Management and Dept. of Animal Nutrition, Genetics \& Breeding, Faculty of Animal Science \& Veterinary Medicine, Sher-e-Bangla Agricultural University.

\subsection{Collection of ovaries and processing}

Collection of ovaries and processing have been performed according to the slight modification as described previously (Jamil et al., 2008). Briefly ovaries from sexually mature goats were collected within 30 min of slaughter from the slaughter house. During collection, ovary was marked whether it is right or left and the presence or absence of corpus luteum (CL) (Figure 1) was also recorded. They were then transported within $2 \mathrm{~h}$ of slaughter to the laboratory in a vacuum flask containing sterilized phosphate buffered saline (PBS) at 25-30 ${ }^{\circ}$ C. Ovary collection times were classified into 2 breeding seasons, i.e. Summer season (July, August and September) and Winter season (December, January and February). Upon arrival at the laboratory the ovaries were then transferred to sterilized petridishes and rinsed thoroughly by phosphate buffer saline at $25{ }^{\circ} \mathrm{C}$ before further processing. The adipose tissues and surrounding bursa were removed from ovaries surface.

\subsection{Evaluation of ovary}

After collection and trimming ovaries were weighed in gm in a digital balance and the weight was recorded in tabular form. The length and width in $\mathrm{cm}$ of left, right, CL-present and CL-absent ovaries measured with a digital slide calipers. There were different size of follicles on the surface of both ovaries. The number of visible follicles on the surface (with or without CL) of ovaries were counted and recorded for further analysis.

\subsection{Oocyte collection and COCs evaluation}

The ovaries were washed 2-3 times in phosphate buffer solution (PBS) at $30^{\circ} \mathrm{C}$. They were then placed in a beaker and kept in a water bath at $30^{\circ} \mathrm{C}$. Each ovary was individually handled, and oocytes were recovered by the following way according to Ramsingh et al. (2013). In aspiration technique, 18-gauge hypodermic needles were used to puncture the ovarian surface. The $10 \mathrm{ml}$ syringe was loaded with D-PBS (1.0-1.5ml) and the needle (18G) was put in the ovary parenchyma near the vesicular follicles and all follicles were aspirated near the point at the same time. After aspirating the follicles from one ovary, the aspirated follicular materials were transferred slowly into a 35-mm Petridishes, avoiding damage to the cumulus cells. Then the petridishes were kept undisturbed for 5 minutes, allowing the COCs to settle down. Then the COCs were searched and graded under an inverted microscope (Olympus, Tokyo, Japan) at low magnification.

\subsection{Categories of COCs}

The COCs were classified according to the method of Khandoker et al. (2001) with slight modification. Briefly quality of cumulus oocyte complexes were analyzed based on layers of granulose cells. There are four categories of cumulus oocyte complexes: category A (good quality), oocytes surrounded by cumulus cells with large quantities (more than 3 layers) and compact with a homogeneous ooplasm, category B (medium quality) the oocytes partially surrounded by less than 3 layers of cumulus cells with homogeneous ooplasm, category C (poor quality) the oocytes not covered by cumulus cells or oocytes surrounded by cumulus cells slightly and category D: degeneration observed both in oocytes and cumulus cells. Here grade A and B were considered as normal COCs and grade $\mathrm{C}$ and $\mathrm{D}$ as abnormal COCs.

\subsection{Statistical analysis}

All values were expressed as Mean \pm SE (Standard Error). The $p$ value greater than 0.05 were considered as nonsignificant and the $p$ value less than 0.05 were considered as significant. Data were analyzed with the SAS (Statistical Analysis System) software using one-way Analysis of Variance (ANOVA).

\section{Results and Discussion}

\subsection{Effect of season on morphology of ovaries}

The ovaries were found almond-shaped structured, pale colored situated in the edge of the mesovarium near the lateral margin of the pelvic inlet (Figure 2). This report corresponds to the report of May (1970). Each ovary had 
an irregular surface by follicles projecting from the surface. The uterine extremity of the ovaries was connected with the extremity of the horn of uterus by a proper ligament of the ovary. There was no demarcation between the horn of the uterus and the flexuous uterine tubes (Figure 2). In left ovaries the mean weight and length were distinctly higher (Table 1$)$ in summer season $[(1.00 \pm 0.11) \mathrm{g}$ and $(1.32 \pm 0.06) \mathrm{cm}$ respectively] compared to that of winter season $[(0.74 \pm 0.07) \mathrm{g}$ and $(1.22 \pm 0.05) \mathrm{cm}$ respectively]. In Nigerian goats the length of the left ovary was $1.71 \pm 0.27 \mathrm{~cm}$ (Adigwe and Fayemi, 2005). This differs with the present study. Species difference may cause this. But width was distinctly higher in left ovaries (Table 1) in winter season $[(0.83 \pm 0.06) \mathrm{cm}$ respectively] compared to that of summer season $[(0.82 \pm 0.05) \mathrm{cm}$ respectively]. In right ovaries the mean weight and width were distinctly higher (Table 1) in summer season $[(1.08 \pm 0.15) \mathrm{g}$ and $(0.91 \pm 0.06) \mathrm{cm}$ respectively] compared to that of winter season $[(0.92 \pm 0.07) \mathrm{g}$ and $(0.85 \pm 0.04) \mathrm{cm}$ respectively], but length was distinctly higher (Table 1$)$ in winter season $[(1.32 \pm 0.04) \mathrm{cm}$ respectively] compared to that of summer season $[(1.29 \pm 0.08) \mathrm{cm}$ respectively].

The observation expressed that in both seasons ovaries were equally active to normal physiological or ovarian activity. The observation also expressed that there was no significant difference $(\mathrm{P}>0.05)$ in the parameters of left ovary in summer and winter seasons of goat. The mean weight and width in the present study were numerically found higher in right ovaries in summer than those of winter season but no significant $(p>0.05)$ differences were found. The mean weight $(\mathrm{gm})$ and width $(\mathrm{cm})$ of right ovaries in summer and the weight $(\mathrm{gm})$, length $(\mathrm{cm})$ and width $(\mathrm{cm})$ of right ovaries in winter were found higher than left ovaries. In Nigerian goats the length of the right ovary was $1.73 \pm 0.27 \mathrm{~cm}$ (Adigwe and Fayemi, 2005). This doesnot match with the present study. This may cause due to species difference. The results of the different qualitative, quantitative parameters of ovaries in two different seasons of Black Bengal goat are summarized in (Table 1). In this study, it was observed that all the qualitative and quantitative parameters of different follicular aspects of left ovary were not similar to the right ovary in goat in two different seasons ( $>>0.05)$. Islam et. al. (2007) worked on goat ovaries and reported that the mean weight, length and width were found higher in right ovaries than those of left ovaries and right ovaries were more active than left ones to show normal physiological or ovarian activity and supports the present study. Normal physiological ovarian activity is that right ovaries are more active than left ones, according to previous reports (Singh et al., 1974; Rahman et al., 1977; Sarkar, 1993). In the present study, values that have not reached statistical significance $(\mathrm{P}>0.05)$ may be ascribable to the species. Same results were found in goat (Islam et al., 2007). But Singh et al. (1974) supports that there was no significant difference $(\mathrm{P}>0.05)$ in the parameters of left and right ovaries of goat.

In corpus luteum-present ovaries the mean weight and length were numerically higher (Figure 3 ) in summer season $[(0.78 \pm 0.32) \mathrm{g}$ and $(1.32 \pm 0.25) \mathrm{cm}$ respectively] compared to that of winter season $[(0.58 \pm 0.15) \mathrm{g}$ and $(1.21 \pm 0.14) \mathrm{cm}$ respectively]. But width was distinctly higher (Figure 3$)$ in winter season $[(0.89 \pm 0.05) \mathrm{cm}$ respectively] compared to that of summer season $[(0.86 \pm 0.20) \mathrm{cm}$ respectively]. No significant $(\mathrm{p}>0.05)$ differences were found in the weight $(\mathrm{gm})$, length $(\mathrm{cm})$ and width $(\mathrm{cm})$ of corpus luteum-present ovary in summer and winter seasons of goat. The CL is an extra cellular part of the ovary which made the differences of its width and weight. The result is very common as the hypertrophy of luteinized granulosa cells, hyperplasty of fibroblasts of the connective tissues and vascularity contribute to an increase in size of the CL (Jablonka-Shariff et al., 1993). The maximum diameter of CL is reached $6 \sim 9 \mathrm{~d}$ after ovulation and then regression starts between days 13 and 16 if maternal recognition does not occur (Jablonka-Shariff et al., 1993).

\subsection{Effect of season on follicular development in ovary}

The number of follicles visible on the surface in relation to the right and left ovaries was counted and presented in (Table 2). The average number of follicles in both left and right ovaries were higher (Table 2) in summer $(12.50 ; 10.48)$ than in winter season $(8.08 ; 8.21)$. No significant $(\mathrm{p}>0.05)$ differences were found in the total number of follicles in left and right ovary in summer and winter seasons of goat. According to (Farag et al., 2010 ) the results revealed that more categories COCs and the total number of recovered oocytes per ovary were aspirated during spring than those collected during winter, summer and autumn seasons. This may attributed to the presence of more follicles during the breeding season (spring). These findings are similar to those reported on sheep by Attia (2001), who found that the reduction in the proportion of good oocytes (class A and B) was evident among those recovered during summer and autumn $(16.46 \%, 24.19 \%$ and $15.76 \%, 23.57 \%)$ than those harvested during winter and spring $(50.83 \%, 57.77 \%$ and $28.90 \%, 28.88 \%)$. It could be suggest that oocytes were compromised during development and differentiation when climatic factor are not ideal for reproduction. The present findings were also supported by Datta and Goswami (1998) who observed that, the average number, as well as, the proportion of good quality oocytes that were retrieved from buffalo ovaries during cool months $\left(<25^{\circ} \mathrm{C}\right)$ was significantly higher than the corresponding values obtained during moderately hot $\left(25-30^{\circ} \mathrm{C}\right)$ and 
hot $\left(>30^{\circ} \mathrm{C}\right)$ periods. They suggested that oocytes are compromised during development and differentiation when climatic factor are not ideal for reproduction. Also, Zohier et al (2007) reported that the proportion of collected number of good buffalo oocytes significantly increased during spring and winter than those collected during summer and autumn (71 and 74.6 vs. 50 and 56.9\%, respectively). In addition, Brück et al. (1996) reported that the rate of oocytes recovery in mare was significantly higher in May/June (57.3\%) than in August / September (44\%). Also, Abdoon (2001) reported that more category (I) and total oocytes per ovary in camel were recovered during the breeding season than non-breeding season. According to (Farag et al., 2010) the author attributed this difference to the presence of more follicles during the breeding season (from February to April). But all this results donot support my observation. More follicles were found during summer season than winter season from my observation. It may happen due to nutritional aspect, temperature or species difference. In summer season grass is more available than winter season. This may be a cause of this findings. In corpus luteum-present ovaries total number of follicles were distinctly higher (Figure 4) in summer season $[(9.00 \pm 1.00)$ respectively] compared to that of winter season [(6.50土1.84) respectively]. In corpus luteum-absent ovaries total number of follicles were distinctly higher (Figure 4) in summer and winter season $(13.52 ; 11.84)$ compared to that of CL-present ovary in summer and winter season $(9.00 ; 6.50)$. No significant $(p>0.05)$ differences were found in the total number of follicles in corpus luteum-present and absent ovary in summer and winter seasons of goat. As follicle bears oocyte, so we can say that more follicle contains more oocyte and less follicle contains less oocyte. According to Nandi et al. (2000) the oocyte recovery rate decreased when ovaries had a corpus luteum and this supports this result.

\subsection{Grading of oocyte}

The oocyte recovery rate (Table 3) (2.20) is higher in summer than in (1.97) winter season. The recovery rate of A, B, C and D grade (Figure 5) of oocytes were found to be 2.20, 2.42, 2.07 and 1.71 (Table 3) in summer and $2.00,1.25,2.42$ and 2.25 in winter. The results obtained in the present study showed that recovery rate of grade $\mathrm{A}$ and $\mathrm{B}$ oocytes were higher in summer than that of in winter and recovery rate of grade $\mathrm{C}$ and $\mathrm{D}$ were higher in winter than that of in summer. The results also obtained in the present study showed that recovery rate of total grade A and B oocytes (2.24) was higher in summer than that of in winter (1.79) and recovery rate of total grade $\mathrm{C}$ and $\mathrm{D}$ was higher in winter (2.33) than that of in summer (1.95). Ovary collection times in goat were classified into 2 breeding seasons, i.e. peak breeding season (September, October, and November) and low breeding season (March, April, and May) (Jamil et al., 2008). The recovery rate of B oocytes and total of A and $\mathrm{B}$ oocytes was significantly higher $(\mathrm{P}<0.05)$ during the summer season than the winter season. The recovery of oocytes was significantly higher $(P<0.05)$ during the peak breeding season than the low breeding season (Jamil et al., 2008). This result supports this findings partially. A similar trend was observed with the recovery of usable oocytes (Jamil et al., 2008). Predojevic et al. (1988) reported that bovine reproduction has a dependency on soil, plant, and climatic factors, particularly in tropical and subtropical parts of the world. Although buffaloes are polyestrous, they exhibit a distinct seasonal variation in breeding activity. Results of other studies performed in Pakistan are consistent with those performed in India; about 64\%-75\% of buffalo exhibited estrus between September and December (Singh et al., 1993). It has been observed that the maximum number of services occurred during the fall season (September, October and November), followed by the winter season (December, January and February) (Shah et al., 1988). The seasonal effect on the incidence of estrus was very significant (P $<0.05$ ). The poor recovery of oocytes during the low breeding season was probably due to the relatively inactive status of ovaries (Perera et al., 1984) that often renders buffalo as seasonal breeders (Pandey et al., 1979). The results of the present study revealed that a significantly higher $(\mathrm{P}<0.05)$ oocyte recovery rate per ovary was obtained from the ovaries collected during the peak breeding season.

According to (Farag et al., 2010) during the study, the average number of COCs categories and total oocytes per ovary were slightly raised during summer than those collected during winter $(1.31 ; 3.68$ vs. $1.26 ; 3.45$, respectively). These findings are similar to those reported by Gou et al. (2009) who observed that proportion of sheep COCs was significantly $(\mathrm{P}<0.05)$ decreased in winter compared to summer and autumn $(51.4$ vs. 84.9 and 83.6\%, respectively). Also these findings are in agreement with those reported by Kadoom et al. (1995) who found that, the total recovery rate of oocytes from buffalo ovaries was higher in summer season than in other seasons. The same findings were also obtained by Seydou et al. (1999) in goat. This findings support this observation. According to Farag et al. (2010) the spring was the best season for recovery of COCs which have a worthy competence to be matured in vitro. Stenbak et al. (2001) reported that IVF of oocytes recovered from superovulated ewes was higher in the breeding season than during the anoestrus. In addition, season influences in vivo fertilization rate, and some studies have shown a greater number of fertilized oocytes recovered from super-ovulated ewes in the breeding season than during the anoestrus (Mitchell et al., 2002; Gonza'lez-Bulnes 
et al., 2003). Changes in semen quality might contribute to the seasonal differences in IVF, but low seasonal variations in the volume and quality of the ejaculates from Rasa Aragonesa rams (Mart1'et al., 2007) suggest that the lower cleavage rates in the anoestrous season might be mainly caused by lower oocyte quality.

\subsection{Effect of season on oocytes recovery in corpus luteum-present and corpus luteum-absent ovary}

In the present study a significantly greater number of oocytes (Figure 6) per ovary were recovered from ovaries without a corpus luteum $(2.23 ; 2.02)$ than from ovaries with a corpus luteum $(1.50 ; 1.50)$. Greater number of oocytes (Figure 6) per ovary were recovered from ovaries with and without a corpus luteum $(1.50 ; 2.23)$ in summer than from ovaries with and without a corpus luteum $(1.50 ; 2.02)$ in winter. No significant $(\mathrm{p}>0.05)$ differences were found in the total number of oocytes in corpus luteum-present and absent ovary in summer and winter seasons of goat. According to Nandi et al. (2000) the oocyte recovery rate decreased when ovaries had a corpus luteum. This is because follicular development is restricted due to lutein cells occupy most of the ovary (Kumar et al., 1997). The dominant follicle is usually observed in the corpus luteum-bearing ovary, and the other follicles are very small and remain mostly inaccessible (Gasparrini et al., 2000). Cow (Moreno et al., 1993) and goat (Agrawal et al., 1992) ovaries containing a corpus luteum yielded a lower number of oocytes than ovaries without a corpus luteum. Several researchers have reported that the presence of a corpus luteum yields a lower number of oocytes per ovary and a lower proportion of usable oocytes (Moreno et al., 1993). In contrast, Boediono et al. (1995) and Das et al. (1996) found no difference in the mean number of oocytes per ovary between corpus luteum-bearing and non-bearing ovaries. In conclusion it was determined that the method of oocyte collection, season, and ovarian status at the time of oocyte collection significantly affects the recovery of usable oocytes for use in IVF programs.

Table 1. Effect of season on qualitative and quantitative parameters in left and right ovary.

\begin{tabular}{|l|l|l|l|l|}
\hline Ovary & Parameter & Summer season & Winter season & Level of significance \\
\hline \multirow{2}{*}{$\begin{array}{l}\text { ovart } \\
\text { Weight }(\mathrm{g})\end{array}$} & $1.00 \pm 0.11$ & $0.74 \pm 0.07$ & NS \\
\cline { 2 - 5 } & Length $(\mathrm{cm})$ & $1.32 \pm 0.06$ & $1.22 \pm 0.05$ & NS \\
\cline { 2 - 5 } Right ovary & Width $(\mathrm{cm})$ & $0.82 \pm 0.05$ & $0.83 \pm 0.06$ & NS \\
\hline & Weight $(\mathrm{g})$ & $1.08 \pm 0.15$ & $0.92 \pm 0.07$ & NS \\
\cline { 2 - 5 } & Length $(\mathrm{cm})$ & $1.29 \pm 0.08$ & $1.32 \pm 0.04$ & NS \\
\cline { 2 - 5 } & Width $(\mathrm{cm})$ & $0.91 \pm 0.06$ & $0.85 \pm 0.04$ & NS \\
\hline
\end{tabular}

Values are shown in mean $\pm \mathrm{SE}$

$\mathrm{NS}=$ Non-significant at $p>0.05$

Table 2. Seasonal effect on number of follicles of ovary.

\begin{tabular}{|l|l|l|l|}
\hline \multicolumn{2}{|c|}{ No. of follicle (Mean \pm SE) } & Level of significance \\
\hline Ovary & Winter season & Summer season & NS \\
\hline Right ovary & $8.08 \pm 0.77$ & $12.50 \pm 2.56$ & NS \\
\hline
\end{tabular}

Values are shown in mean \pm SE

NS=Non-significant at $p>0.05$

Table 3. Grading of oocyte in different seasons.

\begin{tabular}{|c|c|c|c|c|}
\hline \multicolumn{2}{|l|}{ Parameters } & Summer season & Winter season & Level of significance \\
\hline \multicolumn{2}{|l|}{ Total No. of ovaries } & 44 & 44 & -- \\
\hline \multicolumn{2}{|c|}{ Total No. of oocytes } & 97 & 87 & \\
\hline \multicolumn{2}{|c|}{ Oocytes per ovary $($ mean \pm SE) } & $2.20 \pm 0.14$ & $1.97 \pm 0.11$ & NS \\
\hline \multirow{3}{*}{ Normal oocyte } & Grade A & $2.20 \pm 0.16$ & $2.00 \pm 0.13$ & NS \\
\hline & Grade B & $2.42^{\mathrm{a}} \pm 0.36$ & $1.25^{\mathrm{b}} \pm 0.16$ & $*$ \\
\hline & Total & $2.24^{\mathrm{a}} \pm 0.15$ & $1.79^{\mathrm{b}} \pm 0.12$ & $*$ \\
\hline \multirow{3}{*}{ Abnormal oocyte } & Grade C & $2.07 \pm 0.23$ & $2.42 \pm 0.36$ & NS \\
\hline & Grade D & $1.71 \pm 0.18$ & $2.25 \pm 0.31$ & NS \\
\hline & Total & $1.95 \pm 0.16$ & $2.33 \pm 0.23$ & NS \\
\hline
\end{tabular}

Values are shown in mean \pm SE

Mean values in the same column with different superscripts $(a, b)$ differ significantly at $p<0.05$.

$\mathrm{NS}=$ Non-significant at $p>0.05$

* Significant at $p<0.05$ 


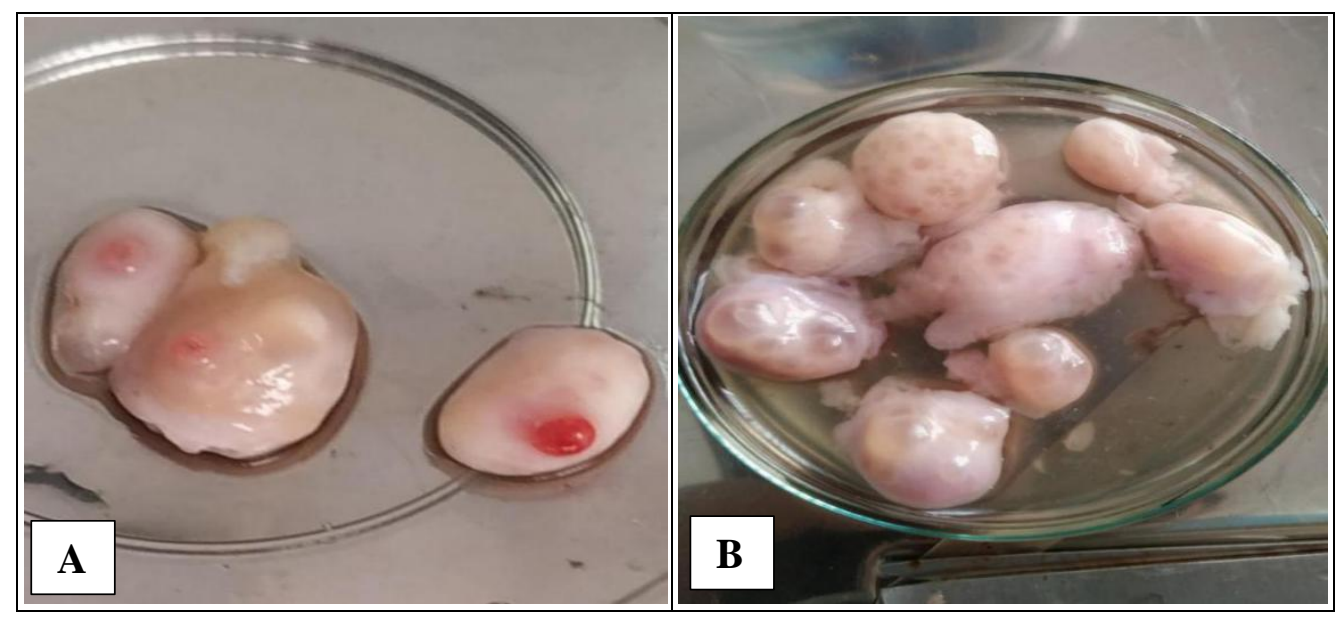

Figure 1. A. CL-present ovaries, B. CL-absent ovaries.
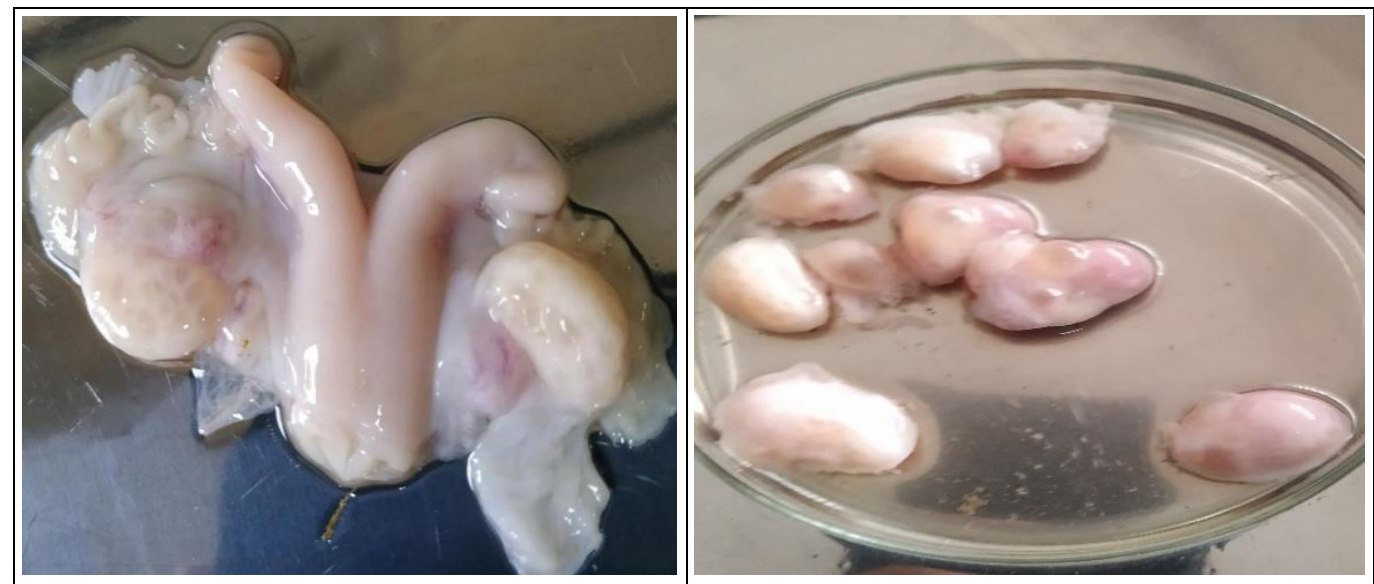

Figure 2. Ovary and associated structures.

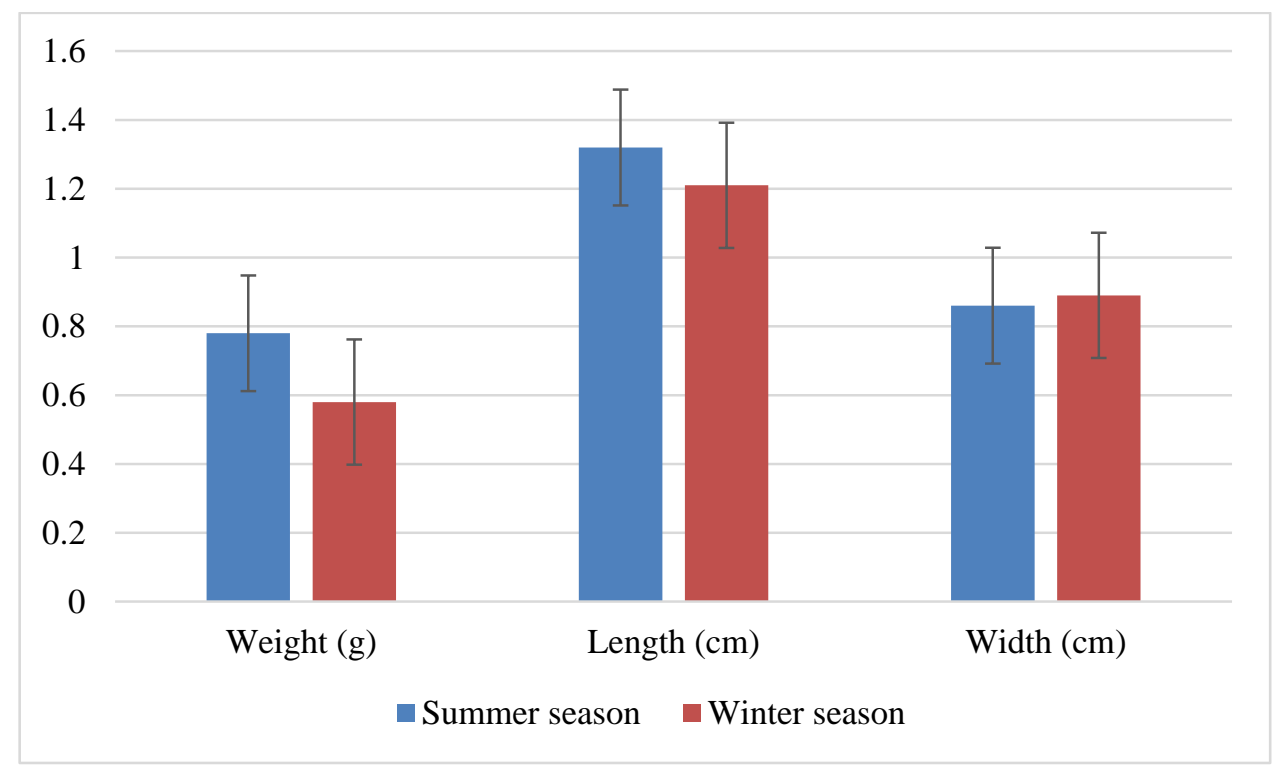

Figure 3. Effect of season on qualitative and quantitative parameters in corpus luteum-present ovary. 


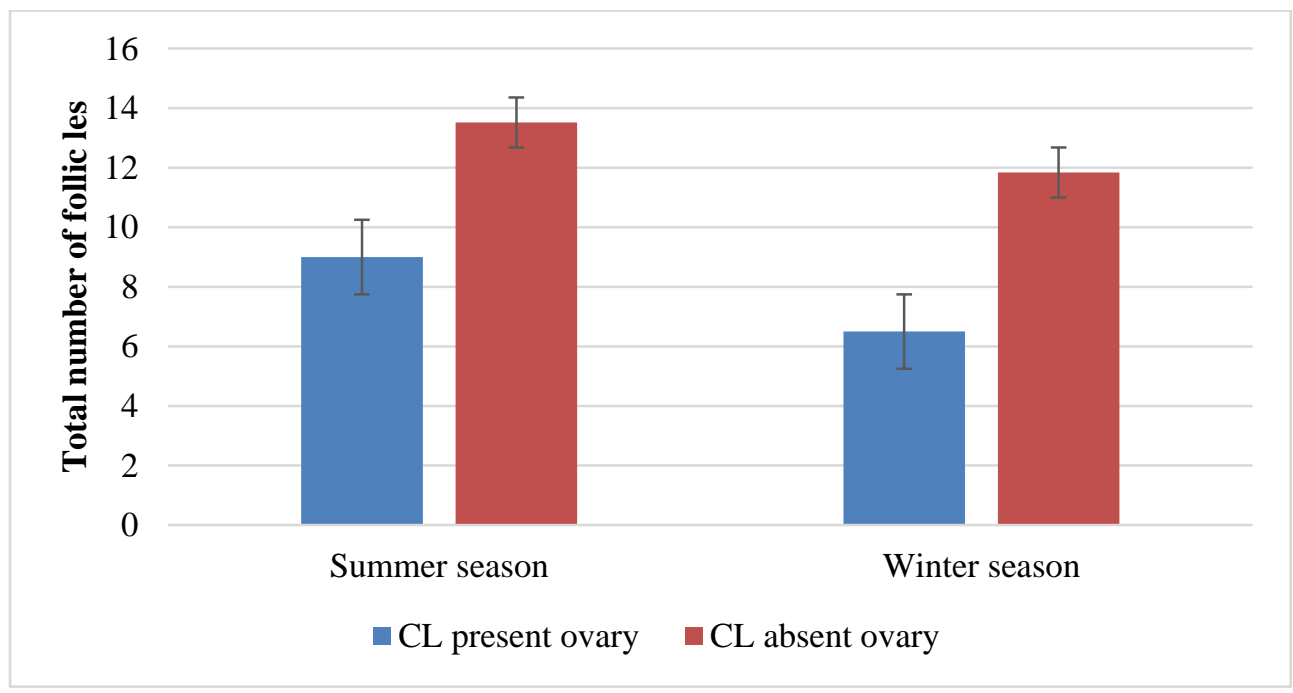

Figure 4. Effect of season on total number of follicles in corpus luteum-present and corpus luteum-absent ovary.

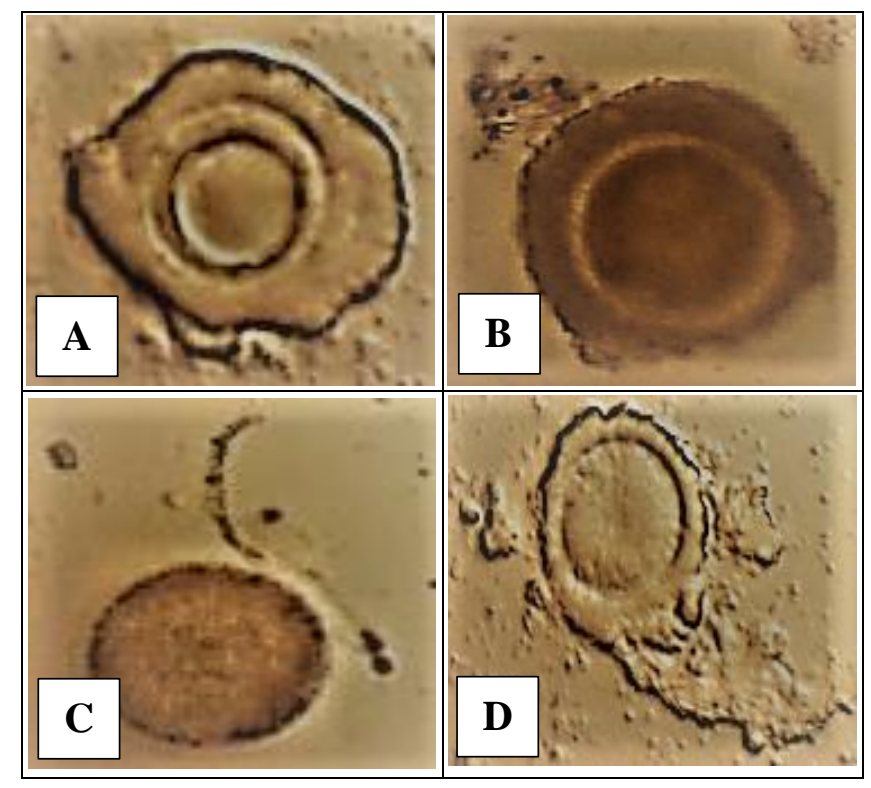

Figure 5. Grading of oocyte, A. Grade A, B. Grade B, C. Grade C, D. Grade D.

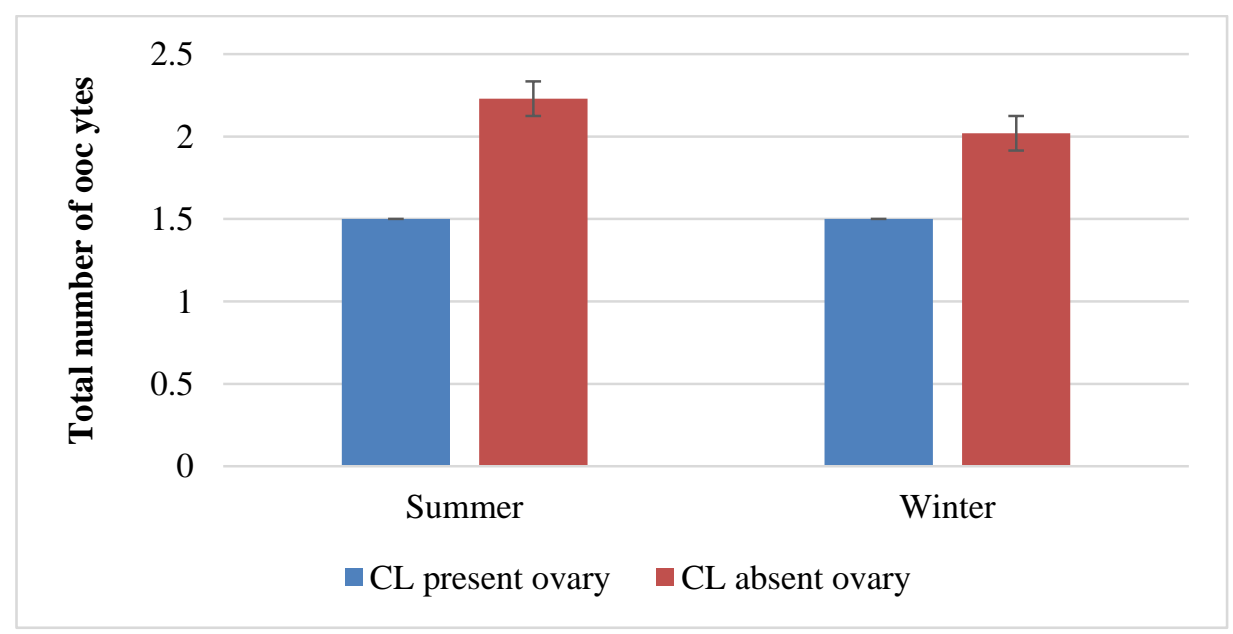

Figure 6. Effect of season on oocytes recovery in corpus luteum-present and corpus luteum-absent ovary. 


\section{Conclusions}

The study revealed that both right and left ovaries were great source for large number of oocyte and without-CL ovaries were considered as a suitable source to supply quality oocyte for in vitro embryo production of goat. The oocyte recovery rate was higher in summer than in winter season. The results obtained in the present study showed that recovery rate of grade A and B oocytes were higher in summer than that of in winter and recovery rate of grade $\mathrm{C}$ and $\mathrm{D}$ were higher in winter than that of in summer. The results also obtained in the present study showed that recovery rate of total grade A and B oocytes was higher in summer than that of in winter and recovery rate of total grade $\mathrm{C}$ and $\mathrm{D}$ was higher in winter than that of in summer. So the summer was the best season for recovery of COCs which have a worthy competence to be matured in vitro. Further studies are required for adopting and improving in vitro embryo production systems (maturation, fertilization and culture) of collected oocytes from local mammalian animals (cattle, buffalo, sheep and goat). Technological manipulation of the mammalian oocytes may increase the production of meat, milk and conserve species.

\section{Acknowledgements}

The author gratefully acknowledges the Ministry of Science \& Technology (MOST) for funding the research.

\section{Conflict of interest}

None to declare.

\section{References}

Abdoon ASS, 2001. Factors affecting follicular population, oocyte yield and quality in camels (Camelus dromedaries) ovary with special reference to maturation time in vitro. Anim. Reprod. Sci., 66: 71-79.

Adigwe PI and O Fayemi, 2005. A Biometric study of the reproductive tract of the Red, Sokoto (Maradi) goats of Nigeria. Pakistan Vet. J., 25: 149-150.

Agrawal KP, 1992. Factors affecting oocyte recovery from caprine ovaries of abattoir origin. In: Recent advances in goat production. R.R. Lokeshwar, Ed., Proc. 5th Int. Conf. Goats, 12071210.

Al-Katanani YM, L Paula and PJ Hansen, 2002. Effect of season and exposure to heat stress on oocyte competence in Holstein cows. American Dairy Science Association. J. Dairy Sci., 85: 390-396.

Attia KHE, 2001. Studies on in vitro fertilization of small ruminant oocytes. Ph.

Boediono A, R Rajamahendran, S Saha, C Sumantri and T Suzuki, 1995. Effect of the presence of a CL in the ovary on oocyte number, cleavage rate and blastocyst production in vitro in cattle. Theriogenology, 43: 169.

Brück I, C Grøndahl, T Høst and T Greve, 1996. In vitro maturation of Equine oocytes: Effect of follicular size, cyclic stage and season. Theriogenology, 46: 75-84.

Colleoni S, AM Luciano and F Gandolfi, 2004. Cumulus-oocyte communications in the horse: role of the breeding season and of the maturation medium. Reprod. Domest. Anim., 39: 70-75.

Das GK, GC Jain, VS Solanki and VN Tripathi, 1996. Efficacy of various collection methods for oocyte retrieval in buffalo. Theriogenology, 46: 1403-1411.

Datta TK and SL Goswami, 1998. Feasibility of harvesting oocytes from buffalo (Bubalus bubalis) ovaries by different methods. Buffalo. J., 2: 277-284.

FAO, 1970. FAO Production Year Book. 1970. Food and Agriculture Organization of United Nations, Rome, Italy.

FAO, 2003. FAO Production Year Book. 2003. Food and Agriculture Organization of United Nations, Rome, Italy.

Farag IM, SM Girgis, NHA Hassan, WKB Khalil, AAM Sakr and NI Ali, 2010. Effect of protein additives on in vitro maturation of Egyptian sheep oocytes with reference to seasonal variation effects on yield and quality of oocytes. J. Am. Sci., 6: 588-599.

Gasparrini B, G Neglia, R Di Palo, G Campanile and L Zicarelli, 2000. Effect of cysteamine during in vitro maturation on buffalo embryo development. Theriogenology, 54: 1537-1542.

Gonza'lez-Bulnes A, RM Garci'a-Garci'a, J Santiago-Moreno, V Domı'nguez, A Lo' pez-Sebastian and MJ Cocero, 2003. Reproductive season affects inhibitory effects from large follicles on the response to superovulatory FSH treatments in ewes. Theriogenology, 60: 281-288.

Gou K, H Guan, J Bai, X Cui, Z Wu, F Yan and X An, 2009. Field evaluation of juvenile in vitro embryo transfer (JIVET) in sheep. Anim. Reprod. Sci., 112: 316 - 324.

Islam MR, MAMY Khandoker, S Aforoz, MGM Rahman and RI Khan, 2007. Qualitative and quantitative analysis of goat ovaries, follicles and oocytes in view of in vitro production of embryos. Journal of Zhejiang University, 8: 465-469. 
Jablonka SA, A Grazul, D Redmer and L Reynold, 1993. Growth and cellular proliferation of ovine corpora lutea throughout the estrous cycle. Endocrinology, 133: 1871-1879.

Jamil H, HA Samad, ZI Qureshi, NU Rehman and LA Lodhi, 2008. Harvesting and evaluation of riverine buffalo follicular oocytes. Turkish Journal of Veterinary and Animal Sciences, 32: 25-30.

Kadoom AKhA, 1995. Studies on in vitro maturation, fertilization and development of buffalo oocytes. Ph.D. Thesis, Department of Gynecology, Obstetrics and A.I., Faculty of Veterinary Medicine, Alexandria University, Egypt.

Khandoker MAMY, K Imai, T Takahashi and K Hashizume, 2001. Role of gelatinase on follicular atresia in the bovine ovary. Biol. Reprod., 65: 720-732.

Kumar A, VS Solanki, SK Jindal, VN Tripathi and GC Jain, 1997. Oocyte retrieval and histological studies of follicular population in buffalo ovaries. Anim. Reprod. Sci., 47: 189-195.

Li F, WH Pi, HZ Zhua, SS Zhang, SR Liu and JL Xue, 2006. The effect of estrous ewe serum and heparin on in vitro fertilization and subsequent embryonic development in sheep. Small Rumin. Res., 63: 226-232.

Martı' E, L Mara, JI Martı', T Muin ̃ o-Blanco and JA Cebria' n-Perez, 2007. Seasonal variations in antioxidant enzyme activity in ram seminal plasma. Theriogenology, 67: 1446-1454.

May NDS, 1970. The Anatomy of the sheep ( ${ }^{\text {rd }}$ Edition). University of Queensland Press, St. Lucia, Queensland.

Mitchell LM, WS Dingwall, MJA Mylneb, J Hunton, K Matthews, FE Gebbie, GJ Mc Callum and TG Mc Evoy, 2002. Season affects characteristics of the pre-ovulatory LH surge and embryo viability in superovulated ewes. Anim. Reprod. Sci., 74: 163-174.

Moreno JF, G Flores-Foxworth, M Westhusin and DC Kraemer, 1993. Influence of pregnancy and presence of a $\mathrm{CL}$ on quantity and quality of bovine oocytes obtained from ovarian follicles aspirated post-mortem. Theriogenology, 39: 271.

Nandi S, MS Chauhan and P Palta, 2000. Effect of a corpus luteum on the recovery and developmental potential of buffalo oocytes. Vet. Rec., 147: 580-581.

Pandey MD and BC Raizada, 1979. Overcoming summer sterility in buffalo bulls and cows. FAO Animal Production and Health, Paper No.13, FAO, Rome, 235-246.

Perera BMAO, LNA De-Silva and AM Karunaratne, 1984. Studies on reproductive endocrinology and factors influencing fertility in dairy and draught buffaloes in Sri Lanka. In: The Use of Nuclear Techniques to Improve Domestic Buffalo Production is Asia. International Atomic Energy Agency, Vienna, Austria, 1328.

Predojevic RM, V Miljkovic, S Perkovic and L Subotin, 1988. The role of climatic factors in bovine reproduction. In: 11th Int. Congr. Anim. Reprod. Artif. Insem. Dublin, 3: 415.

Rahman A, A Hossain, M Ahmed and M Sen, 1977. Studies on some reproductive performances and biometry of the female genital tract of Black Bengal goat. J. Anim. Sci., 47: 714-725

Ramsingh L, K Sadasivarao and K Muralimohan, 2013. Ovarian biometrics and oocyte grading percentage of yield in local goats of andhra pradesh. Iosr Journal Of Pharmacy, 3:47-49

Ravindranatha BM, S Nandi, HM Raghu and SM Reddy, 2003. In vitro maturation and fertilization of buffalo oocytes: effects of storage of ovaries, IVM temperature, storage of processed sperm and fertilization media. Reprod. Domest. Anim. Feb., 38: 21-26.

Sarkar M, 1993. Studies on the Incidence of Reproductive Abnormalities in Female Goat (Capra hircus) Mymensingh, Bangladesh: Bangladesh Agricultural University. Master of Science Thesis Submitted to the Dept. of Anatomy.

Seydou S, G Oladele, A Eugene and G Seyoum, 1999. The effects of serum source and hormone supplementation on goat oocytes maturation, fertilization and early embryo development during the nonbreeding season. Society for the study of reproduction, 32nd Annual Meeting, July 31- August 3, 1999.

Shah SNH, 1988. Coparative study of seasonal influence on breeding behaviour and conception rate of dairy buffalo and zebu cattle. In. Proc. 11th Int Congr. Anim. Reprod. Artif. Insem., 3: 538.

Silva CC, HJD Rosa and PG Knight, 2006. Seasonal variations in the developmental competence of bovine oocytes matured in vitro. Vet. Rec., 158: 473475.

Singh SK, AR Bhattacharay and SN Luktura, 1974. Studies on biometry of genital organs of female goat. 51: 81-85.

Singh R and AS Nanda, 1993. Enviromental variables governing seasonality in buffalo breeding. Indian J. Anim. Sci., 71: 119 (abstr).

Stenbak TK, DA Redmer, HR Berginski, AS Erickson, C Navanukraw and MJ Toutges, 2001. Effects of follicle stimulating hormone (FSH) on follicular development, oocyte retrieval, and in vitro fertilization (IVF) in ewes during breeding season and seasonal anestrus. Theriogenology, 56: 51-64. 
Zoheir KM, AS Abdoon, KF Mahrous, MA Amer, MM Zaher, LG Yang, and EM El-Nahass, 2007. Effects of season on the quality and in vitro maturation rate of Egyptian buffalo (Budalus bubalis) oocytes. J. Cell Anim. Biol., 1: 29-33. 